\title{
Status and Barriers of Classroom-based student Assessment Practices in Geography at Secondary level in Nepal
}

\author{
Shambhu Prasad Khatiwada \\ geography.dmc@gmail.com
}

\begin{abstract}
The main focus of this article is to analyze the status and barriers to effective use of classroom-based student assessment practices for geography teacher at secondary levels. The data for this paper were generated from the empirical study. The purposive sampling method was used to select both communities (12) and institutional (4) schools from different Provinces as well as ecological zones. This paper concludes that the majority of geography teachers still use traditional means of student assessment practices, such as terminal exams, half-yearly exams, and annual exams. Some teachers have used both paper-pencil test and classroom-based student assessment practice in general and particular in geography subject. But the number of such teachers is very low. The classroom-based student assessments such as homework, class work, group discussion, project work and so on are an integral part of geography teaching. This paper has also identified barriers of effective use of classroom-based assessment practiced.
\end{abstract}

Key Words: Classroom, assessment, geography, teachers, barriers, curriculum

\section{Introduction}

Geography has been defined as a discipline that surveys the relationship between man and the environment and its spatial variable. The geography department established in Germany in 1870s has provided a specialist educational contribution to knowledge, and its main growth of the discipline came in the twentieth century (Taylor, 1985 cited as in Hall \& Page, 2014 p. 19). The Presidential addresses of the Association of American Geographers Susan Cutter (2002) considered the pedagogical importance of geography education in both developed and developing countries like Nepal. Human interactions with each other and the environment are rooted in geographical understandings, as well as the opportunities and constraints of geographical circumstance. Geographical approaches and techniques offer critical insights into everything from local land-use decisions to international conflict.

Geography is one of the oldest academic disciplines in both school and university levels in Nepal. In Nepal, the history of geography as an academic field of study dates back to the beginning of the $20^{\text {th }}$ century, although the use of geographic ideas, concepts and geographical description of the place go back to the Vedic period (Subedi \& Poudel, 2005). J.P.B. Singh was 
recognized as the first person who introduced the geography subject in the school curriculum in 1901 and it was developed an organized subject after the establishment of SLC Board in 1934.

The government of Nepal has considered the importance of teaching geography either as an optional subject from school to university levels as well as geographic aspect are taught in social studies as a compulsory subject after the recommendation of National Education Commission in 1992 and the National Curriculum Framework 2006 with the amendment 2014. Curriculum Development Center (CDC) has prepared a curriculum of school-level geography subject as based on this framework. The curriculum covers different themes, such as physical geography, regional geography, human geography, economic geography, and practical geography. Indeed, Indian curriculum has covered the area of physical geography, human geography, regional geography, field study and tools and techniques (CDC, 2001). The curriculum has adopted all the principles of curriculum development processes in secondary level (Class 9 and 10) in general and geography subject in particular. The curriculum includes the significance of teaching geography at the school level, general objectives, and specific objectives, teaching methods and evaluation process in 2006. Curricula have prescribed both formative (constructive) and summative (decisive) assessments processes to measure student learning achievement. Assessment is the primary method educators use to discover what students have learned in their courses. That may sound fairly straightforward, but in reality, assessment is a complex issue that has many facets (https://www.proprofs.com).

In Nepal, geography is taught at the school level as an elective subject and geographic concept in social studies taught as a compulsory subject. Therefore, in this article, the teachers who taught either geography or geographic concepts at the secondary level is considered as a geography teacher. They used various types of student assessment practices such as preparative (diagnostic), formative and summative. Thus, this paper seeks to unravel the question, can the status and barriers of classroom-based student assessment practices are a field of geographic study? To answer this question this paper attempt to analyze the status and barriers of classroom-based student assessment practices in the secondary level geography curriculum in Nepal.

\section{Conceptual discussion}

Geography attempts to bridge the widening gap between the changing physical and biological phenomena on the one hand, and the changing human phenomena on the other (James, 1972). Therefore, geography can be divided into relatively two disciplines: physical geography, which concerns with the physical world, and human geography which concerns with the human world (Norton, 2004). These trends represent some philosophies, some methodologies, and some ideologies with regard to the purpose of academic geography (Johnston, 1991). These concepts, principles, methods, and philosophy provide subject matters for teaching geography at various levels.

This paper argues that any teacher who teaches geography or geographic concepts should first understand the subject matters of geography. Only then, s/he should use student assessment methods and tools for evaluating the learning achievement of the student. The teacher, who cannot understand the themes of geography, uses limited means of assessment practices for measuring geographic skills in the classroom. For this purpose, the National curriculum framework: 
NCF (2006) further modified and used in this paper. The National Curriculum Framework and geography curriculum have been recommended both formative and summative assessment practices to measure student progress in grade 9 to 10 . However, a majority of teachers still used in various forms of summative assessment practices such as statutory, optional test, annual-teacher made test, and other external tests. But the curriculum considers that formative assessment is an integral part of teaching-learning in general and geography subject in particular.

An assessment for learning is a phrased employ for diagnostic assessment, assessment for learning is used for formative assessment and assessment of learning is utilized for summative assessment (Ebel \& Frisbie, 1991; Pollard, 2002). Pollard (2002) summarizes the findings of the Assessment Reform Group (ARG, 1999) as follows:

The important message now confronting the educational community is that assessment which is explicitly designed to promote learning is the single most

According to Black \& William (as cited by Pollard 2002) formative assessment should be productive, pupils should be trained in self-assessment so that they can understand the main purposes of their learning and thereby grasp what they need to for improved achievement. Moreover formative assessment help provide remedial teaching for the weak student through classroom work, homework, project work, monthly test, unit test and extra-curricular activities.

\section{Method}

This paper is based on empirical study. For this purpose, sixteen schools were selected by purposive sampling method with covering three ecological zones and Provinces. Twelve community schools and 4 institutional schools were selected from urban and rural areas. Respondents were selected from different groups, such as teachers, students, parents, head teachers, Resource Persons, School Supervisors, District Education Officers, CDC personnel and Confederation of Nepali Teacher (CNT) representatives. Primary data were collected from observation, interview and focus group discussion. Archive documents and records had also been reviewed to get secondary data.

\section{Result and Discussions}

\section{Status of classroom-based student assessment practices in geography}

This paper reveals that the geography curriculums in the secondary level have been designed to provide knowledge of geographical, cultural, economic, human aspects of the world. These knowledge comprises through different branches of geography such as physical, human, regional, tools and techniques and field study. The curriculum also provides comprehensive knowledge about the geographical and cultural diversity of Nepal. For this purpose a geography teacher requires an array of understanding and abilities regarding to student evaluation practices. S/ he can use decisive (summative) or formative evaluation practice to evaluate varied fields of geographic knowledge and skills. The result indicates that only one assessment method cannot measure all aspects of geographic skills and student learning achievement. In this situation, classroom-based student assessment practice is more useful to measure different aspects of geography through field observation, project works, practical works, class works, group works 
and teacher student interaction methods. Because classroom-based student assessment practice is a continuous process and it is an integral part of teaching in general and geography in particular is helpful for both teachers and students to find out the effectiveness of teaching-learning activities (Khatiwada, 2011).

This paper reveals that the majority of secondary level teachers still use paper-pencil based test such as terminal test, half-yearly and annual examination. Most of the public schools have not been able to use classroom-based student evaluation which is more likely to improve the learning achievement. Their perceptions indicated that student assessment has been widely practiced to identify the number of students pass or fail, to inform the parent of the level of student's progress, and to upgrade the class for further study. Khatiwada, Acharya \& Chongbang (2018) have also found similar results in their study in Nepal. The students' views about the current uses of student assessment practiced at schools are very relevant. The synthesis reports of being as follows:

In our school, classroom-based student assessment practices are very weak. The focus of geography teachers is to complete the lesson before time; they have, no matter what the student learned knowledge, skills, and behavior allocated in the curriculum. However, all the teachers ask oral questions at the end of the lesson. But the limited numbers of teachers have used homework, group work, and discussion to measure our learning achievements before starting another lesson.

Classroom-based student assessment is helpful to find out what students have learned - the outcome of the instruction in the class. The Head teachers reported about the benefits of this assessment to improve teaching-learning activity as follows:

In our schools, quarterly exams, semi-annual and annual exams widely practiced measuring student progress in all subjects. But, we have not been taken classroom-based student assessment as an integral part of teaching activities in general and geography in particular.

They further stated that:

Nowadays, the situation has changed. We take regular exams every Saturday. It has helped us in our preparation for SEE and other qualified tests with good practices. Students are always busy in the classroom concerning classwork, different types of examination and discussion on the subject matter with friends to foster our learning.

The geography teachers share their experiences as follows:

We have used different types of classroom-based student assessment practices, such as presentation, group discussion, group work and collaboration, field study and project work to enhance the inherent capacities of the students in geography. It helps us to ensure that the students' interest and curiosity, helping students' to find out and clarify what they think, and helping students to relate what they have learned to their everyday lives. 
The Confederation of Nepali Teachers (CNT) has both positive and negative views regarding the use of a formative assessment practice at the secondary level as follows:

Theoretically, a classroom-based assessment is more useful where those schools have well-equipped geography classroom and ideal student numbers. There are a lot of dilemmas regarding the effective use of the formative assessment practice in geography classroom: such as student-teacher ratios, lack of induction training, inappropriate instructional planning, and lack of teacher competency towards formative assessment practiced at the secondary level.

Head teachers have reported that the teacher is a single authority of the classroom teachinglearning activities. Those teachers who participated in teacher professional development (TPD) training have good knowledge in instructional planning. The TPD has organized a separate session on student assessment systems in the classroom with practice. Unless the majority of the teachers still do not seem to effective use of the classroom-based student assessment practice that has learned from the TPD training. If 50 percent of the teachers learned from the training have been used effectively in the classroom, it helps to improve student learning achievement.

The Resource Person views collectively claimed that the limited use of classroom-based assessment in the classroom as follow:

The teacher's social-cultural background affects the classroom environment and teaching-learning activities at first. The teacher does not even show 10 percent talent of knowledge, skill and concept learned from training in the classroom in the second. The novice teacher does seem to be able to use a range of formative-assessment tools in the classroom, but senior teachers have pressured them to the continuity of traditional assessment methods in the third.

On the other hand, most of the schools are bringing students to educational tour, but this tourism seems to be limited only to entertainment activities than teaching improvement.

The result indicates that the majority of teachers appear to be in favor of classroom-based student assessment practices. But various factors have prevented them from using it effectively in the geography classroom. But some teachers openly opposed it. Their perceptions reveal that the classroom-based student assessment practice increased a burden to teachers due to more time consuming and jig-jack to record keeping. As a result, the majority of teachers are still practicing paper-pencil test. They have reported that written examinations seem to be easy to evaluate student's progress, to keep records and to inform students' achievements to their parents.

Nowadays, the situation has been gradually changing, the Head teachers requested from the teachers using classroom assessment practices such as homework, class work, unit test, class observation, monthly test and project work. The teachers, students, and parents have followed to the view of the Head teachers. This campaign of Head teachers indicates that some schools have gradually improved in the learning achievements in community schools. 


\section{Comparison across Geographical Regions}

Classroom-based student assessment of the study area does not appear in the same way in all geographical regions and Provinces. These variations revealed among the schools located in the mountains, hills, and Tarai; East and West; urban and rural; and community and institutional schools. For example, schools were taken from different locations, such as Dolpa, Gorkha and Rasuwa from the mountains; Dadeldhura, Surkhet, Argahkanchi, Kaski, Tanahu, Dhankuta from the hills; Bhaktapur from the Kathmandu valley; and Sunsari, Mahottari, Bara, Chitwan, Rupendehi and Dang from the Tarai. The class observation result shows that some changes have noticed in classroom-based student assessment practices both community and institutional schools, while their numbers are very low.

On the basis of their result, schools can be divided into three groups. They are successful schools who improve classroom-based student assessment practices in the first; second, the school realized the need for classroom-based student assessment, improvement; and third, the school did not pay attention to classroom-based student assessment improvement. The result indicates that Surkhet, Kailali, Kaski and Bara districts fall under the first category. It follows Dang, Rupendehi, Chitwan, Bhaktapur, Mahottari, and Sunsari districts in the second and in the third belonging to Dhankuta, Gorkha, Tanahu, Arghakhanchi, Rasuwa, and Dolpa districts. The spatial distribution of the first category schools by ecological regions reveals that about 50 percent schools are to be found in the Tarai (Kailali and Bara) and 50 percent in the Hills (Kaski and Surkhet). It was $83.33 \%$ in the Terai and $16.67 \%$ in the mountains only in the second category as compared to 50 percent each of the hills and mountains in the third category.

Urban-rural continuum is another measure to identify the present status of classroom-based student assessment practices by the location of schools. The result indicates that the schools located in the urban areas (62.5\%) have frequently used homework, class work, project work, unit tests, and monthly tests as compared to the rural areas $(37.5 \%)$. This improvement has increased the number of students' from institutional and community schools every year. The schools of Mahottari and Kailali (Tarai), Dhankuta and Tanahu (hills), Gorkha and Rasuwa (Mountain) districts were in the rural areas and Sunsari, Chitwan, Rupendehi and Dang (Tarai); Arghakhanchi, Surkhet, Dadeldhura (hills) and Dolpa districts in the urban.

The weekly test often held on Friday or Saturday was more popular in the urban areas. The result indicates that only 25 percent of teachers have been using student-centered teaching methods such as question-answer, group discussion, class work, group works, and homework. However the result reveals that only 25 percent of the total numbers of teachers (16) have regularly implemented different types of classroom-based student assessment practices in the hills and it was relatively higher in the Tarai and Surkhet. They argue that classroom-based assessment helps us to know how the student learns the lessons they have studied and what they ought to be worked on next. It is also important to understand how that knowledge will help us to shape the students further learning. 


\section{Barriers to practice classroom-base student assessment}

The result shows that the application of the classroom-based student assessment practice in the study area is at an initial stage as compared to traditional evaluation systems. Despite this, some signs of improvement that have noticed after the various policy efforts provided by the Ministry of Education and donor agencies in Nepal. Teachers sometimes think that all supports and assistance must come from them. It is mainly due to the diverse classroom demands diverse teaching approaches. The geography teacher overcoming the barriers regarding this issue said:

Medium of instruction, high student-teacher ratio, teachers' daily increased workload, the old architectural designed classrooms, complex student evaluation tools and format, parents give less priority to the community schools, poor student learning achievement, unequal teacher allocation system, limited human and financial resources and very weak monitoring and evaluation system.

This paper reveals that the barriers of classroom-based student assessment are time-consuming, lack of professional training to handling classroom-based assessment, student-teacher ratio, faulty methods in teacher allocation, lack of on the induction training, lack of knowledge of classroombased assessment, lack of appropriate instructional planning, lack of teacher's competency to use of specification chart in question selection, and misconception about the classroom-based assessment system. Although a teacher plan a wide range of activities, from classwork, group discussion to demonstration, field visit, practical and experimental works. They argued that:

All students integrate into a cooperative learning team. Each member of the group always has a special job, like the material collection, preparation, and presentation. We want all students to have the chance to work in ways that are comfortable for them.

About 90 percent teachers from the sampled schools have not considered neither the recommendation of National Curriculum Framework nor the various education commissions and projects for evaluating students' performance in the classroom. On the other hand, SSDP (2016) is designed to enable the school education sector to "ensure equitable and inclusive quality education and promoting lifelong learning opportunities for all'. The teacher reports:

We usually used various methods of student evaluation practices in the classroom, such as class work, homework, extracurricular activities, creative work, question answer and regular attendance. To accomplish all these activities we need more time. If we prefer to use summative assessment it will save both time and effort by using the paper-pencil test. In our opinion, most of the teachers have not been allowed time and effort to practice formative assessment in the community school. It requires extra time and energy, so, more time consuming without any extra pay is one of the challenges or limited use of formative assessment tools.

The result indicates that more than 85 percent schools the ratio of teacher-student have comparatively added than the national average in a class. When the scholar asked teachers how much they teach, they often answer that they teach 5-7 periods in a day, but when the question was asked to the Head teachers, they answered it is 6 periods on average. When a teacher is 
absent on a holiday, the class should be recovered by additional teachers which also increases the class loads. It shows that the working load varies from school to school. For this reason a teacher is unable to spare extra-time for feedback and intensive support on an individual basis.

The teachers reported that they have always evaluated student knowledge through a recall test, or by asking content questions during a lecture. About 30 percent of teachers have been practicing the different types of classroom-based assessments. However, all teachers have realized that the evaluation provides them feedback on students, and ensure betterment in the teaching-learning process. At this point, it is found that the evaluation results had not been used seriously for further improvement of the classroom practices.

For classroom-based assessment purposes, those dynamics have to center on keeping students believing in themselves. It isn't merely about getting teachers more information so they can make better instructional decisions. Good classroom-based assessment practices keep students believing that success is within reach if they keep trying.

\section{Conclusion}

The synthesis of respondents' views traces out ways that can be delivered in classroom-based student assessments that reflect more closely the work that students and teachers create in the classroom. But the teachers who graduated in any discipline are legitimated to teach social studies in general and geographic concept, in particular, do not know the fundamental principles of teaching geography. So they do not even effectively use all types of student evaluation methods in the classroom. The concerning authority should be increased teachers' ability to teach geographical concepts and to assess the dignity of the geography subject at the secondary level.

This paper indicates that some of the barriers of the classroom-based student assessment practice at the secondary level in geography such as lack of proper allocation of subject teachers, the teachers who specialize in other disciplines to teach geographical concepts, teachers' daily working loads are more than 6 periods, and lack of a specialist of geography education as a teacher trainer.

The findings of this paper indicate that those schools have improved in the teaching-learning environment, they have changed the medium of instruction and increased school and parent interaction seems to have changed student evaluation gradually. But those schools that have not been able to improve these are still dependent on traditional student evaluation. The factors like parent-teachers interaction, participatory planning and implementation, teamwork, visionary school administration, laborious teachers and students and effective monitoring and evaluation systems are also playing the significant role to improve classroom-based student assessment practices.

\section{References}

CDC (2001).Report of the curriculum development committee in geography, New Delhi: University Grant Commission. 
CDC (2006).Secondary education curriculum, part II. Bhaktapur: Curriculum Development Center, Ministry of Education, Science and Technology.

CDC (2016).Secondary education curriculum, part II. Bhaktapur: Curriculum Development Center, Ministry of Education, Science and Technology.

Hall, C.M. \& Page, S. J. (2014).The geography of tourism and recreation: environment, place and space, London: Routledge.

James, P.E. (1972). All possible worlds: a history of geographical ideas, Indianapolis: The Odyssey Press.

Johnston, R.J. (1991). Geographers and geographers: Anglo-American human geography since 1945. London: Arnold Publishers.

Khatiwada, S. P. (2011). Teaching geographic concepts in social studies: perspective on teaching-learning activities. Nepalese journal of of educational studies. Kathmandu: Central Department of Education, 1 (1), pp.107-112.

Khatiwada, S. P., Acharya, B. R..\& and Chongbang, K. B. (2018). An analysis of student assessment practice at school level in Nepal. A Research Report Submitted to the Education Review Office Sanothimi, Bhaktapur.

NCF, (2006).The national curriculum framework for school education in Nepal.Ministry of Education, Kathmandu.

Norton, W. (2004).Human geography, New York: Oxford University Press.

Pollard, A. (2002). Reflective teaching: effective and evidence-informed professional practice. London: Continuum

Subedi, B. P. \& Poudel, P.C. (2005). Geography and geographers work in Nepal: an introduction. In Subedi, B. P. \& Poudel (eds.) Geography and geographers work in Nepal: reflections on mountain environment and human activities. Kathmandu: Nepal Geographical Society, Central Department of Geography, and National Center of Competence in Research (North-South), pp.1-10.

http://www.jotscroll.com/forums/3/posts/183/geography-definition-types-scope-subject-matterbranches-of-geography.html

https://www.proprofs.com/c/lms/what-is-student-assessment/ 